\title{
EVALUATION OF SOFT TISSUE REGENERATIVE PROCESSES AFTER SUBCUTANEOUS IMPLANTATION OF SILVER/ POLY(VINYL ALCOHOL) AND NOVEL SILVER/POLY(VINYL ALCOHOL)/GRAPHENE HYDROGELS IN AN ANIMAL MODEL
}

\author{
Tijana LUŽAJIĆ BOŽINOVSKI ${ }^{1}$, Vera TODOROVIĆ ${ }^{2}$, Ivan MILOŠEVIĆ ${ }^{1}$, \\ Vladimir GAJDOV 5 , Bogomir Bolka PROKIĆ ${ }^{3}$, Katarina NEŠOVIĆ \\ Vesna MIŠKOVIĆ-STANKOVIĆ ${ }^{4}$, Danica MARKOVIĆ ${ }^{1 *}$
}

\begin{abstract}
${ }^{1}$ Faculty of Veterinary Medicine - Department of Histology and Embryology, University of Belgrade, Bulevar oslobođenja 18, 11000 Belgrade, Serbia; ${ }^{2}$ School of Medicine of University of Zenica Department of Histology and Embryology, Travnička cesta 1, 72000 Zenica, Bosnia and Hercegovina; ${ }^{3}$ Faculty of Veterinary Medicine - Department of Surgery, Orthopedics and Ophthalmology, University of Belgrade, Bulevar oslobođenja 18, 11000 Belgrade, Serbia; ${ }^{4}$ Faculty of Technology and Metallurgy, University of Belgrade, Karnegijeva 4, 11000 Belgrade, Serbia; ${ }^{5}$ Faculty of Veterinary Medicine, University of Belgrade, Bulevar oslobođenja 18, 11000 Belgrade, Serbia
\end{abstract}

(Received 29 May, Accepted 19 June 2021)

A newly produced biomaterial is necessarily subject of standards, which are performed in vivo on animal models. For the evaluation of soft tissue regenerative possibilities after subcutaneous implantation of biomaterials - silver/poly(vinyl alcohol) (Ag/PVA) and novel silver/poly(vinyl alcohol)/graphene (Ag/PVA/Gr) provided for clinical use, sixteen rats were used, according to the instructions of international standards, ISO 10993-6, 2007. Histological sections were observed 7, 15, 30 and 60 days after grafting. These hydrogels were produced by in situ electrochemical synthesis of silver nanoparticles in the polymer matrices, which enabled obtaining completely safe and biocompatible materials, free from any additional toxic chemical reducing agents. Surgical implantation of hydrogels was done according to the permission of the Ethical Committee of the Faculty of Veterinary Medicine, University of Belgrade. Immunohistochemical (IHC) studies included the assessment of smooth muscle expression actin in blood vessels ( $\alpha$-SMA), the expression of laminin and type I and type III collagen in the skin structures, and, the determination of cell proliferation marker expression (Ki-67) keratinocytes. The results were assessed in a semiquantitative manner. The data were analyzed in the statistical software package IBM SPSS 20 . The conclusions indicated that $\mathrm{Ag} / \mathrm{PVA} / \mathrm{Gr}$ might be used as wound dressings to enhance the tissue healing potential and established faster integration and shorter retention in the tissue.

Key words: immunohistochemistry, nanocomposite biomaterials, rat, skin regeneration

\footnotetext{
*Corresponding author: e-mail: danica@vet.bg.ac.rs
} 


\section{INTRODUCTION}

Biomaterials such as hydrogels, mimicking the extracellular matrix (ECM) of tissues, may improve wound healing [1-3]. Poly(vinyl alcohol) (PVA), a synthetic polymer, whose in vitro biocompatibility has been shown in numerous studies, is often used in regenerative medicine [4-6]. The same is true for silver nanoparticles/PVA (AgNPs/ PVA) composite materials [7]. Polymer-based wound dressings are the subject of many studies because there is a wide range of possibilities for their topical application, with the purpose of quickly restoring the skin defects and reducing the risk of infection and further injury [8-11]. In recent years, incorporation of graphene (Gr) in PVA hydrogels has been used in order to improve their mechanical strength and durability [12-15]. Furthermore, Gr has been reported to exhibit antibacterial activity, which could provide additional positive effects together with AgNPs [16]. Although Gr, as an inorganic component, is generally not considered to be very biodegradable. Recent studies have shown that Gr-based materials biodegradability is catalyzed by human eosinophil peroxidase [17]. Moreover, for various hydrogel applications, such as wound dressing and wound care, biodegradability might not be the key property, and it even might be considered a drawback, since a dressing needs to maintain its structure, elasticity and mechanical strength for long periods of time, in order to provide the proper support and protection to the wound during the healing process [18]. Gr and Gr oxide have often been used as fillers for wound dressings and drug delivery materials [19-21]. AgNPs with excellent antibacterial activity are often used as active component in biomaterials based on PVA hydrogels [22-26]. The silver/ poly(vinyl alcohol) (Ag/PVA) and silver/poly(vinyl alcohol)/graphene (Ag/PVA/Gr) hydrogels have been fully characterized [26,27], and are intended for use in biomedical purposes, primarily as wound dressings [10]. The electrochemical method of in situ AgNPs synthesis directly inside the hydrogel matrix, stands out as a completely green process that does not make use of chemical reducing agents, such as $\mathrm{NaBH} 4$ that are toxic and difficult to remove from the dressing material. Therefore, these novel AgNPs-loaded hydrogels are completely non-toxic and biocompatible, as proven by our in vitro biological investigations that also indicate strong antibacterial activity [25]. Our presented data confirmed the biocompatibility of the novel Ag/PVA/Gr hydrogel after in vivo implantation [27].

Rodents are a very common animal model for the evaluation of the regeneration of skin defects and wounds [28-31]. There are evident differences in skin structure and the healing process between humans, other animals, and rats [29,32]. The regeneration of rat skin tissue is faster and more effective in comparison with many other species including humans. Skin healing time in rats is less than 5 days, mostly owing to skin contraction, while the same process takes about 12-14 days or longer in humans, depending on wound size [31,33].

In this study, we discuss some aspects of the repairing processes that occur during experimental trials in the rat soft tissue, following the interactions with the implanted 
novel nanocomposite hydrogels. Several significant histological parameters of skin regenerative processes have been analyzed and evaluated in terms of speed and success of skin recovery.

\section{MATERIALS AND METHODS}

\section{Materials}

The following chemicals were utilized for nanocomposite hydrogels preparation: poly (vinyl alcohol) powder (fully hydrolyzed, $M \mathrm{w}=70-100 \mathrm{kDa}$; Sigma Aldrich, USA), silver nitrate (M. P. Hemija, Serbia), potassium nitrate (Centrohem, Serbia), graphene nanopowder (Graphene Super-market, USA). Ultra-pure water was obtained from the Milli-Q system (Millipore, USA) and was used in all experiments.

\section{Electrochemical synthesis, physico-chemical characterization and in vitro biocompatibility examination}

In situ electrochemical synthesis process of silver-doped poly(vinyl alcohol)/graphene composite hydrogels, their physico-chemical and thermal properties have been described in our previous work [26]. In vitro biological investigation, i.e. examination of the cytotoxicity and antibacterial activity of these hydrogels has been established $[22,23]$.

\section{In vivo experiment}

\section{Animals and experimental protocol}

Sterilized Ag/PVA, Ag/PVA/Gr nanocomposite hydrogel discs, as well as commercial Suprasorb ${ }^{\circledR}$, a calcium alginate dressing (Lohmann \& Rauscher GmbH \& Co. KG, Neuwied, Germany) were implanted in the subcutis of 16 anesthetized adult female rats. Surgical hydrogel implantation was performed in accordance with the international standard ISO 10993-6 2007. The surgical procedure was approved by the Ethical Commitee of the Faculty of Veterinary Medicine, University of Belgrade (no. 01-488, 22.07.2016.). The surgical procedure was performed under general injection anesthesia, by intraperitoneal administration of $75 \mathrm{mg} / \mathrm{kg}$ ketamine hydrochloride (Ketamidor $10 \%, 100 \mathrm{mg} / \mathrm{ml}$, RICHTER PHARMA AG, Austria) and $10 \mathrm{mg} / \mathrm{kg}$ xylazine (Xylased $2 \%$, BIOVETA, Czech Republic). Before the implantation, butorphanol, $1 \mathrm{mg} / \mathrm{kg}$ (Nembutal, OAK) was administered subcutaneously for analgaesia. After that, the operative site was shaved and disinfected with a solution of povidone-iodide. During the preparation and operation procedure, the experimental animals were under constant monitoring by using a veterinary monitor (Votem v7 Patient-monitor, Korea). The animals were sacrificed by an intraperitoneal injection of pentobarbitone solution, $160 \mathrm{mg} / \mathrm{kg}$ (Euthasol 400mg/ml, Produlab BV, The Netherlands). The experimental materials were retrieved from the subcutaneous tissue 7, 15, 30 and 60 days postimplantation (p.i.d.). 


\section{Tissue processing for immunohistochemistry}

Tissue sections were used to determine the $\alpha$-SMA ( $\alpha$-smooth muscle actin antigen) (ab124964) (Abcam, UK), laminin (ab11575) (Abcam, UK), type I (ab34710) (Abcam, UK) and type III collagen (ab6310) (Abcam, UK), Ki-67 (cell proliferation marker) (ab16667) (Abcam, UK) expression in the skin above the implantation zone, capsule and pericapsular area. Visualization of these markers was performed using a highly sensitive and specific two-stage indirect immunohistochemical (IHC) technique, where secondary antibodies labeled with horseradish peroxidase are directly bound to dextran polymers (Thermo Scientific UltraVision LP Detection System/HRP Chromero \& DAB TL-060-HD, Lab Vision, USA).

\section{Semiquantitative evaluation of $\alpha-S M A$, laminin, type I and III collagen expression}

Alpha-SMA IHC staining was used for blood vessels visualization, since the antibody for this intermediate filament stains smooth muscle cells in the tunica media of all blood vessels, including the microvascular bed and pericytes. A semiquantitative method was used to assess the degree of vascularization of the capsule and pericapsular zone. The method used is a points-based system, starting from 1 going up to 4 pluses, where blood vessels occupy up to $10 \%, 30 \%, 31-50 \%$ and over $50 \%$ of the observed surface, respectively. The expression of laminin was assessed semiquantitatively in the structural elements of the skin and subcutaneous tissue. Type I and III collagen expression was performed in the connective tissue of the dermis, hypodermis and cutaneous muscle. All samples were assessed in a semiquantitative manner $(1+$, mild; $2+$, moderate; and 3+, strong).

\section{Estimation of Ki-67 positive keratinocytes}

In the epidermis, proliferating keratinocytes $\left(\mathrm{Ki}-67^{+}\right)$of the basal layer were counted and expressed as the total number of $\mathrm{Ki} 67^{+}$cells per 100 basal keratinocytes. Cells were counted in five representative areas of each sample, using an ocular mesh of $0.250 \mathrm{~mm}^{2}$, magnification 40x.

All of these measurements were performed on a standard Olympus CX31 microscope and processed with CellSens Entry morphometric measurement software (Olympus, Tokyo, Japan). Histological samples were recorded with an Olympus UC50 digital camera.

\section{Statistical analysis}

The data was analyzed in the statistical software package IBM SPSS 20. Variance analysis for repeated measurements was performed within the general linear model. All results were expressed as mean \pm standard error (SE). The minimum level of statistical significance was set at $\mathrm{p}<0.05$. 


\section{RESULTS}

\section{Expression of $\alpha$-SMA in blood vessels, the capsule and pericapsular zone vascularization degree}

The vascularization degree of the connective tissue capsule and the pericapsular zone was high during all observed time periods $\left(7^{\text {th }}, 15^{\text {th }}, 30^{\text {th }}\right.$ and $60^{\text {th }}$ p.i.d.), after $\mathrm{Ag} / \mathrm{PVA}$ and $\mathrm{Ag} / \mathrm{PVA} / \mathrm{Gr}$ implantation (Figure $1 \mathrm{~A}-\mathrm{H}$ ). Blood vessels in these experimental groups occupied $30 \%$ to $50 \%$ of the capsule zone and $10 \%$ to $30 \%$ of the surrounding connective tissue located in the pericapsular zone, in all observed time periods (Table

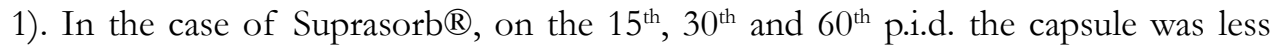
vascularized compared to the $7^{\text {th }}$ p.i.d. where the blood vessels occupied from $10 \%$ to $30 \%$ of the capsule zone (Figure 1I-L). Regarding the degree of vascularization of the pericapsular connective tissue zone, it was similar to the values obtained from

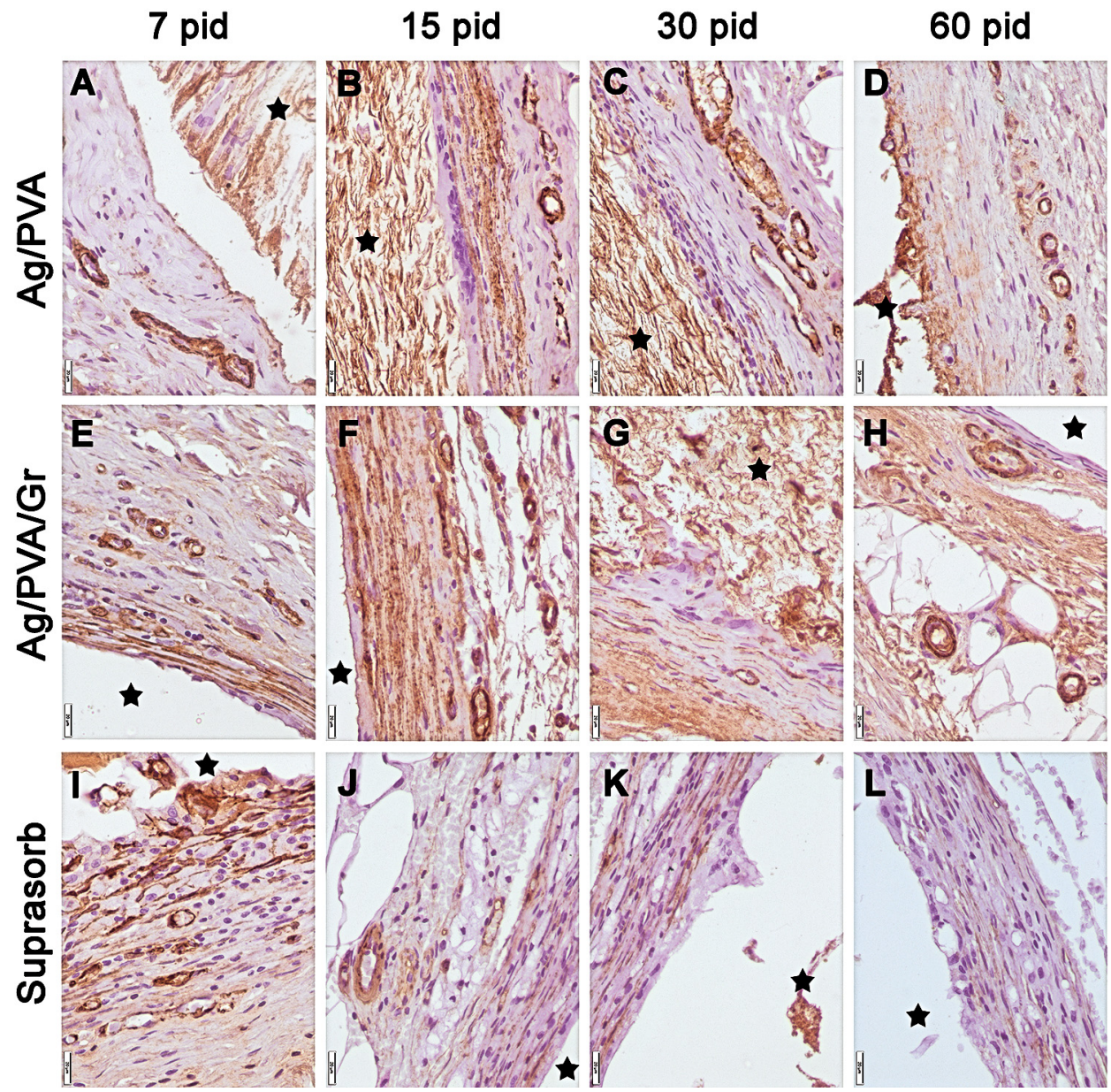

Figure 1. The capsule and pericapsular zone vascularization of $\mathrm{Ag} / \mathrm{PVA}, \mathrm{Ag} / \mathrm{PVA} / \mathrm{Gr}$ and Suprasorb ${ }^{\circledR}$ (star) through the observed follow-up periods. bar:20 $\mu \mathrm{m}$ 
the other implants (Ag/PVA and Ag/PVA/Gr) (Table 1). IHC data showed increased smooth muscle actin expression in the blood vessels of the skin and periimplant zone, which indicates moderate to high degree of neovascularization.

Table 1. Vascularization of the capsule and the connective tissue around the capsule

\begin{tabular}{cccc}
\hline \multirow{2}{*}{$\begin{array}{c}\text { Postimplantation day } \\
\text { (p.i.d.) }\end{array}$} & \multicolumn{3}{c}{ Semiquantitative assessment of the vascularization degree } \\
\cline { 2 - 4 } $\mathbf{7}$ p.i.d. & Ag/PVA & Ag/PVA/Gr & Suprasorb ${ }^{\circledR}$ \\
capsule & +++ & +++ & +++ \\
pericapsular zone & ++ & ++ & ++ \\
15 p.i.d. & & & \\
capsule & ++ & +++ & ++ \\
pericapsular zone & ++ & ++ & ++ \\
$\mathbf{3 0}$ p.i.d. & & & ++ \\
capsule & +++ & +++ & ++ \\
pericapsular zone & ++ & ++ & \\
$\mathbf{6 0}$ p.i.d. & & & ++ \\
capsule & +++ & +++ & ++ \\
pericapsular zone & ++ & ++ & ++ \\
\hline
\end{tabular}

blood vessels occupy up to $10 \%$ of observed surface (+); blood vessels occupy up to $30 \%$ of observed surface $(++)$; blood vessels occupy $31 \%-50 \%$ of observed surface $(+++)$; blood vessels occupy over $50 \%$ of observed surface $(++++)$

\section{Expression of laminin in the skin and periimplant zone after hydrogels implantation}

Laminin in intact skin is expressed by epidermal cells and their derivatives sebaceous gland epithelial cells and hair follicles, in the subcutis, in the connective tissue surrounding adipocytes and in the cutaneous muscle cells. The expression of laminin in the blood vessels of the subcutis and cutaneous muscle cells is similar to the expression in the blood vessels of the dermis. In addition, this expression in the skin after subcutaneous implantation of $\mathrm{Ag} / \mathrm{PVA}$ and $\mathrm{Ag} / \mathrm{PVA} / \mathrm{Gr}$, on the $7^{\text {th }}$ and $15^{\text {th }}$ p.i.d. was very similar to the observations in intact skin (Figure 2A, B; Table 2). The expression level decreased on the $30^{\text {th }}$ and $60^{\text {th }}$ p.i.d. for both hydrogels, and were higher than the samples of the intact skin control by about $40 \%$ (Table 2). However, the pattern of laminin expression during the follow-up p.i.d. somewhat differed in the case of the subcutaneously implanted Suprasorb®. The degree of laminin expression on the $15^{\text {th }}, 30^{\text {th }}$ and $60^{\text {th }}$ p.i.d. was far higher than on the $7^{\text {th }}$ p.i.d., and was higher than the expression in the samples of intact skin (Figure 2C; Table 2). Regarding Ag/PVA and $\mathrm{Ag} / \mathrm{PVA} / \mathrm{Gr}$ implants, the laminin expression in the capsule and pericapsular zone were moderate on the $7^{\text {th }}$ and $15^{\text {th }}$ p.i.d (Figure 2D, E) and weak on the $30^{\text {th }}$ and $60^{\text {th }}$ p.i.d. (Table 2). In contrast, laminin expression in the connective tissue capsule and periimplant zone surrounding Suprasorb ${ }^{\circledR}$ was significantly higher compared to the other observed hydrogels on the $15^{\text {th }}, 30^{\text {th }}$ and $60^{\text {th }}$ p.i.d. (Figure $2 F$, Table 2). Laminin 
was most strongly expressed in these histological zones on the $15^{\text {th }}$ and $30^{\text {th }}$ p.i.d. after Suprasorb® implantation (Figure 2F, Table 2).

Table 2. Semiquantitative assessment of laminin expression in the structural elements of the skin, capsule and pericapsular zone

\begin{tabular}{|c|c|c|c|c|}
\hline \multirow[t]{2}{*}{ Hydrogel/ observed structure } & \multicolumn{4}{|c|}{$\begin{array}{l}\text { Laminin expression in structural elements of the skin, } \\
\text { capsule and pericapsular zone }\end{array}$} \\
\hline & Ag/PVA & Ag/PVA/Gr & Suprasorb® & Intact skin \\
\hline \multicolumn{5}{|c|}{$15^{\text {th }}$ post implantation day } \\
\hline 1. Epidermis & +++ & +++ & +++ & +++ \\
\hline $\begin{array}{r}\text { Sebaceus gland } \\
\text { Hair follicle } \\
\text { M. arrector pili } \\
\text { blood vessels } \\
\text { stroma } \\
\text { fibroblasts }\end{array}$ & $\begin{array}{c}++ \\
++/+++ \\
++/+++ \\
++ \\
0 \\
+\end{array}$ & $\begin{array}{l}++ \\
++ \\
++ \\
++ \\
0 \\
+\end{array}$ & $\begin{array}{c}++/+++ \\
++/+++ \\
++ \\
+/++ \\
0 \\
1\end{array}$ & $\begin{array}{l}++ \\
++ \\
++ \\
+ \\
0 \\
+\end{array}$ \\
\hline 3. Hypodermis & $\begin{array}{c}+ \\
++\end{array}$ & $\begin{array}{c}+ \\
++\end{array}$ & $\begin{array}{c}+ \\
++\end{array}$ & $\begin{array}{l}+ \\
+\end{array}$ \\
\hline 4. M. cutaneus & ++ & + & ++ & ++ \\
\hline Total score $(1+2+3+4), \max .30$ & $18.0 / 30$ & $15.0 / 30$ & $19.0 / 30$ & $15.0 / 30$ \\
\hline \multicolumn{5}{|c|}{$30^{\text {th }}$ post implantation day } \\
\hline 1. Epidermis & $++/+++$ & +++ & +++ & + \\
\hline $\begin{array}{r}\text { Sebaceus gland } \\
\text { Hair follicle } \\
\text { M. arrector pili } \\
\text { blood vessels } \\
\text { stroma } \\
\text { fibroblasts }\end{array}$ & $\begin{array}{l}++ \\
+/++ \\
\quad+ \\
+ \\
0 \\
+\end{array}$ & $\begin{array}{c}++ \\
+ \\
++ \\
+ \\
0 \\
+\end{array}$ & $\begin{array}{c}+++ \\
+++ \\
+++ \\
++ \\
0 \\
+\end{array}$ & $\begin{array}{l}+ \text { /+ } \\
+ \\
+ \\
+ \\
+ \\
0 \\
+\end{array}$ \\
\hline 3. Hypodermis & $\begin{array}{l}+ \\
+\end{array}$ & $\begin{array}{l}+ \\
+\end{array}$ & $\begin{array}{c}+ \\
++\end{array}$ & $\begin{array}{l}+ \\
+\end{array}$ \\
\hline 4. M. cutaneus & ++ & ++ & $++/+++$ & + \\
\hline Total score $(1+2+3+4), \max .30$ & $14.0 / 30$ & $14.0 / 30$ & $23.0 / 30$ & $9.5 / 30$ \\
\hline Hydrogel/ observed structure & Ag/PVA & $\mathrm{Ag} / \mathrm{P}$ & $/ \mathrm{Gr}$ & Suprasorb® \\
\hline \multicolumn{5}{|c|}{$15^{\text {th }}$ post implantation day } \\
\hline 5. Capsule & ++ & & & +++ \\
\hline 6. Pericapsular zone & ++ & & & +++ \\
\hline Total score $(5+6), \max 6$ & $4 / 6$ & & & $6 / 6$ \\
\hline \multicolumn{5}{|c|}{$30^{\text {th }}$ post implantation day } \\
\hline 5. Capsule & + & & & +++ \\
\hline 6. Pericapsular zone & + & & & +++ \\
\hline Total score $(5+6), \max 6$ & $2 / 6$ & & & $6 / 6$ \\
\hline
\end{tabular}




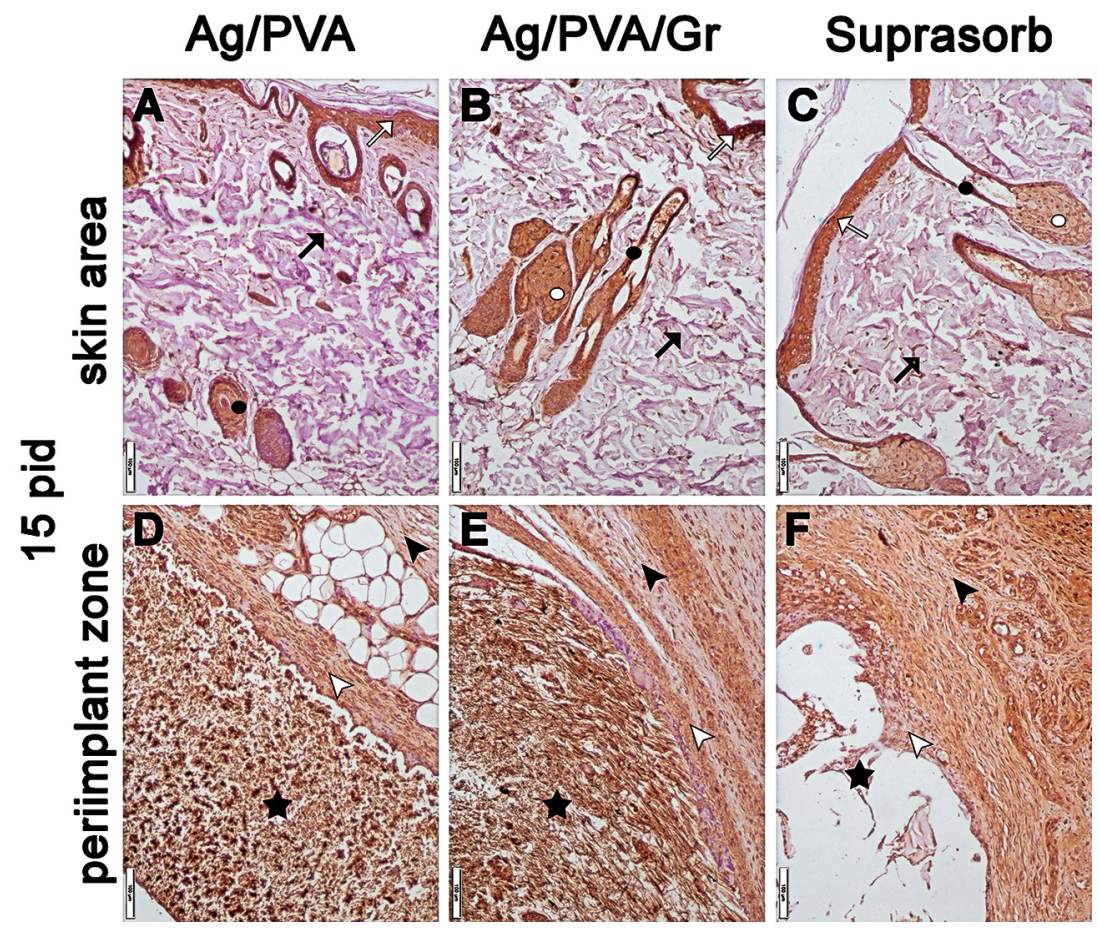

Figure 2. Laminin expression in structural elements of the skin (white arrow - epidermis, black arrow - dermis, black dot - hair follicle, white dot - sebaceus gland) and subcutaneous tissue (A, B, C); Connective tissue capsule (white arrow head) and periimplant connective tissue (black arrow head) $(\mathbf{D}, \mathbf{E}, \mathbf{F})$ after the application of different hydrogels (star) on the $15^{\text {th }}$ p.i.d. bar: $100 \mu \mathrm{m}$

\section{Expression of type I and type III collagen in the skin and periimplant zone after application of hydrogels}

Collagens type I and III were expressed in the connective tissue of the dermis, hypodermis and cutaneous muscle in the intact control skin and the skin after implantation of all three hydrogels. The highest expression was detected in the dermis and such an expression pattern remained unchanged throughout the follow-up period (Table 3). The expression of type I and III collagen was similar in both areas: the capsule and periimplant zone (Figure 3A-F). Regarding Ag/PVA and Ag/PVA/Gr hydrogels, the capsule and the pericapsular subcutaneous connective tissue in the pericapsular zone had mild to moderate expression of type I and III collagen on the $15^{\text {th }}, 30^{\text {th }}$ and $60^{\text {th }}$ p.i.d., while the collagen expression after Suprasorb $®$ implantation was weaker (Table 3). Slightly increased expression was observed around the capsule in the case of $\mathrm{Ag} / \mathrm{PVA} / \mathrm{Gr}$ on the 7 th p.i.d. compared to collagen expression in the case of Ag/PVA and Suprasorb ${ }^{\circledR}$ (Table 3). 
Table 3. Semiquantitative assessment of collagen type I and III expression in the structural elements of the skin, capsule and pericapsular zone

\begin{tabular}{|c|c|c|c|c|}
\hline \multirow{2}{*}{$\begin{array}{l}\text { Hydrogel/ observed structure } \\
\text { C.T. - connective tissue }\end{array}$} & \multicolumn{4}{|c|}{$\begin{array}{l}\text { Coll type I and Coll type III expression in structural } \\
\text { elements of the skin, capsule and pericapsular zone }\end{array}$} \\
\hline & Ag/PVA & Ag/PVA/Gr & Suprasorb ${ }^{\circledR}$ & Intact skin \\
\hline \multicolumn{5}{|c|}{$7^{\text {th }}$ post implantation day } \\
\hline C.T. of the dermis & ++ & ++ & ++ & ++ \\
\hline C.T. of the hypodermis & + & + & + & + \\
\hline C.T. of the M. cutaneus & + & + & + & + \\
\hline Total score (max. 9) & $4 / 9$ & $4 / 9$ & $4 / 9$ & $4 / 9$ \\
\hline \multicolumn{5}{|c|}{$15^{\text {th }}$ post implantation day } \\
\hline C.T. of the dermis & ++ & ++ & ++ & ++ \\
\hline C.T. of the hypodermis & + & + & + & + \\
\hline C.T. of the M. cutaneus & + & + & + & + \\
\hline Total score (max. 9) & $4 / 9$ & $4 / 9$ & $4 / 9$ & $4 / 9$ \\
\hline \multicolumn{5}{|c|}{$30^{\text {th }}$ post implantation day } \\
\hline C.T. of the dermis & ++ & ++ & ++ & ++ \\
\hline C.T. of the hypodermis & + & + & + & + \\
\hline C.T. of the M. cutaneus & + & + & + & + \\
\hline Total score (max. 9) & $4 / 9$ & $4 / 9$ & $4 / 9$ & $4 / 9$ \\
\hline \multicolumn{5}{|c|}{$60^{\text {th }}$ post implantation day } \\
\hline C.T. of the dermis & ++ & ++ & ++ & ++ \\
\hline C.T. of the hypodermis & + & + & + & + \\
\hline C.T. of the M. cutaneus & + & + & + & + \\
\hline Total score (max. 9) & $4 / 9$ & $4 / 9$ & $4 / 9$ & $4 / 9$ \\
\hline Hydrogel/ observed structure & Ag/PVA & $\mathrm{Ag} / \mathrm{PI}$ & & Suprasorb® \\
\hline \multicolumn{5}{|c|}{$7^{\text {th }}$ post implantation day } \\
\hline Capsule & + & + & & + \\
\hline Pericapsular zone & + & + & & + \\
\hline \multicolumn{5}{|c|}{$15^{\text {th }}$ post implantation day } \\
\hline Capsule & $+/++$ & +1 & & + \\
\hline Pericapsular zone & ++ & + & & + \\
\hline \multicolumn{5}{|c|}{$30^{\text {th }}$ post implantation day } \\
\hline Capsule & $+/++$ & +1 & & + \\
\hline Pericapsular zone & ++ & + & & + \\
\hline \multicolumn{5}{|c|}{$60^{\text {th }}$ post implantation day } \\
\hline Capsule & $+/++$ & +1 & & + \\
\hline Pericapsular zone & ++ & + & & + \\
\hline
\end{tabular}



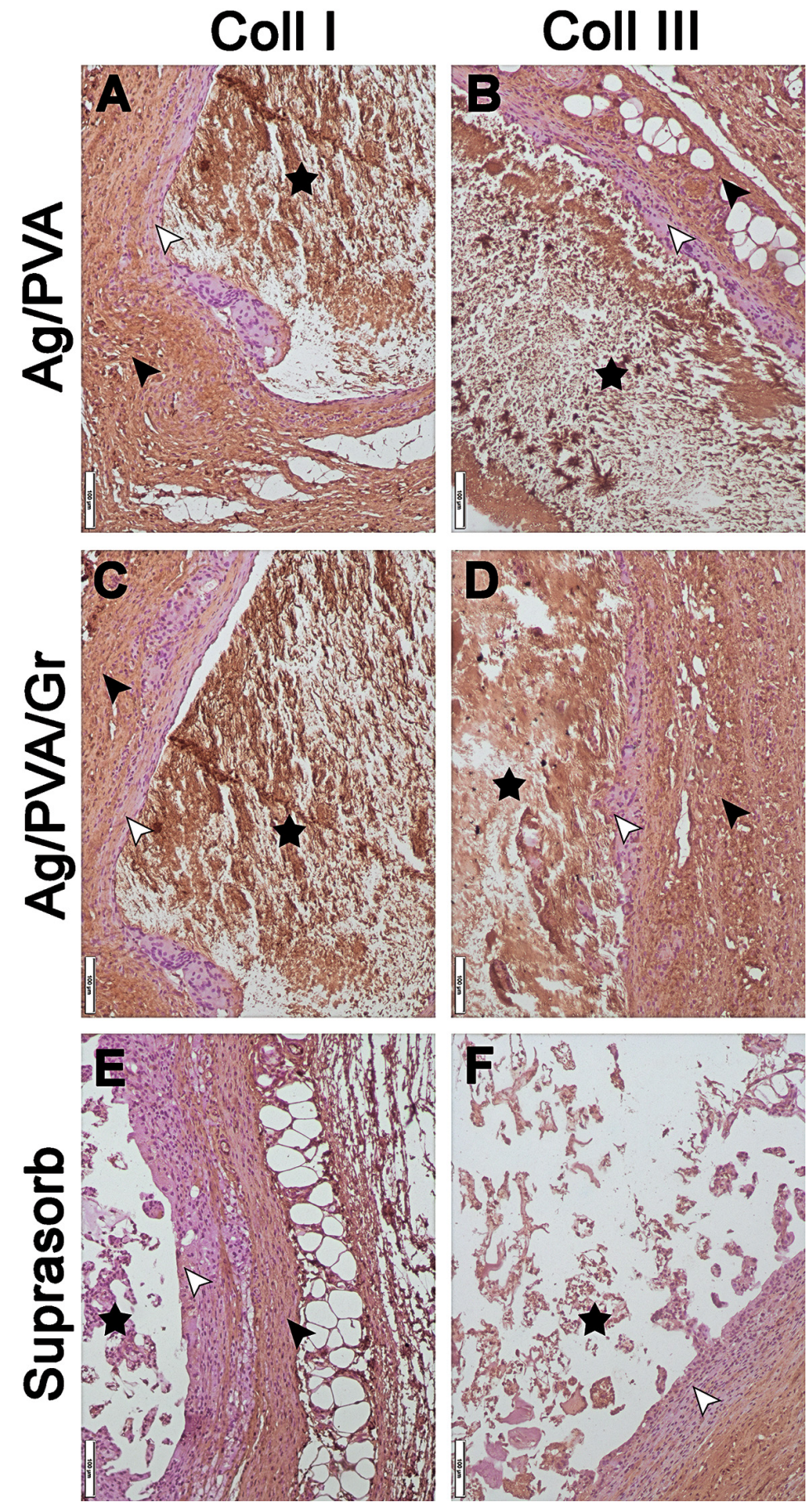

Figure 3. Coll type I and Coll type III expression in connective tissue capsule (white arrow head) and subcutaneous periimplant connective tissue (black arrow head) after the application of different hydrogels (star) on the $15^{\text {th }}$ p.i.d. bar:100 $\mu \mathrm{m}$ 


\section{Proliferation of keratinocytes in the skin and periimplant zone after subcutaneous implantation of hydrogels}

IHC determination of $\mathrm{Ki} 67+$ expression was used to calculate the proliferation index of epithelial cells in the skin (Figure 4D). The keratinocytes number in the epidermis above the implantation zone of the two examined hydrogels was highest on the $7^{\text {th }}$ p.i.d. (Figure 4E). On the $15^{\text {th }}$ p.i.d. these values were significantly higher in the case of $\mathrm{Ag} /$ PVA and Ag/PVA/Gr hydrogels in relation to Suprasorb ${ }^{\circledR}$ (Figure 4 E). Numerous populations of keratinocytes with a high mitotic index were observed in the basal layer of the epithelium (Figure 4 A, B, C, E). That number gradually decreased in the case of $\mathrm{Ag} / \mathrm{PVA}$ and $\mathrm{Ag} / \mathrm{PVA} / \mathrm{Gr}$ implants, from the $30^{\text {th }}$ to the $60^{\text {th }}$ p.i.d. (Figure $4 \mathrm{E}$ ). The commercial Suprasorb ${ }^{\circledR}$ stimulated proliferation on the $60^{\text {th }}$ p.i.d. (Figure $4 \mathrm{E}$ ). When comparing Ag/PVA and Ag/PVA/Gr hydrogels, higher values were observed in the case of $\mathrm{Ag} / \mathrm{PVA}$ in relation to $\mathrm{Ag} / \mathrm{PVA} / \mathrm{Gr}$, both on the $15^{\text {th }}$ and $30^{\text {th }}$ p.i.d. (Figure 4A, B, E).

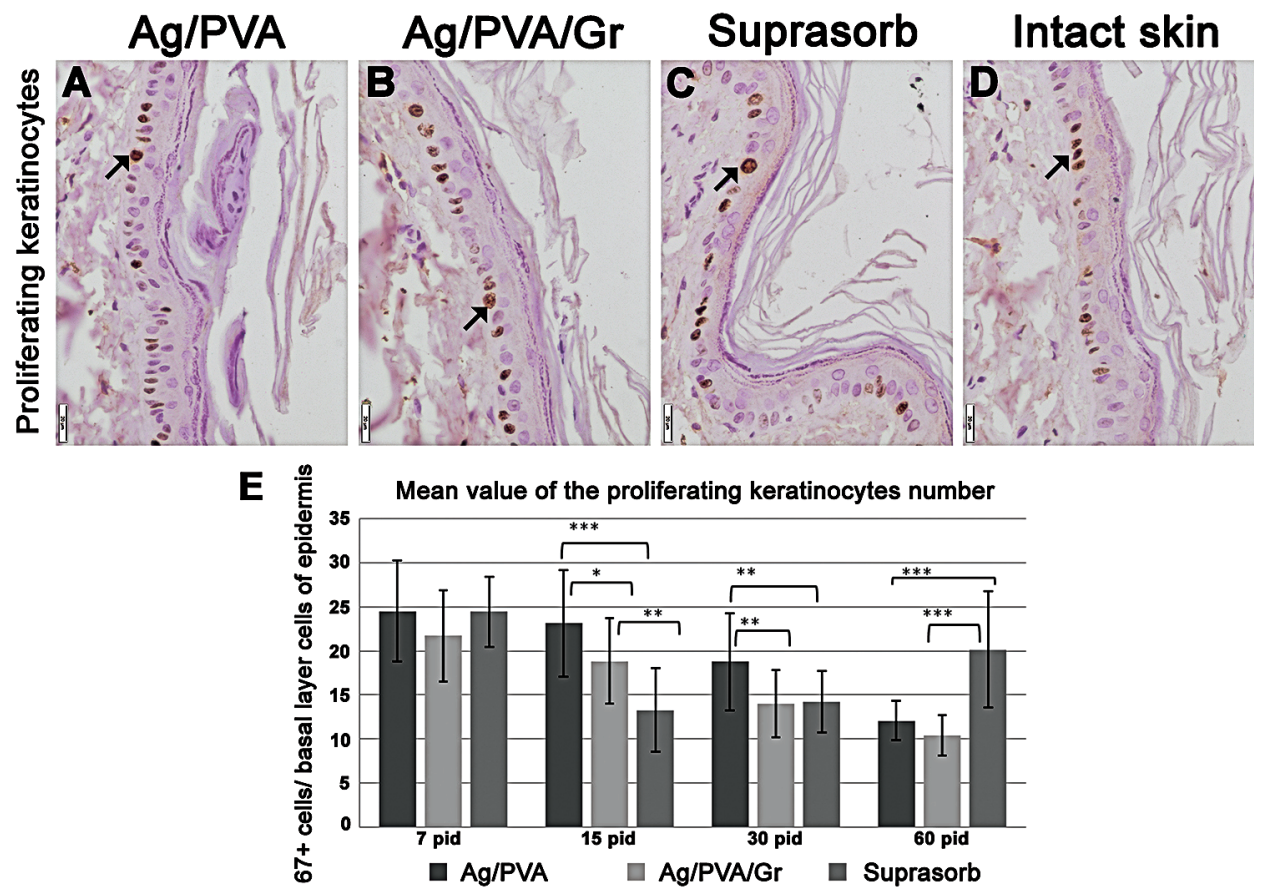

Figure 4. Proliferating keratinocytes (black arrow) of epidermis basal layer after subcutaneous implantation of Ag/PVA (A), Ag/PVA/Gr (B), Suprasorb ${ }^{\circledR}$ (C) and control intact skin sample (D) at the $15^{\text {th }}$ p.i.d. bar: $20 \mu \mathrm{m} \mathbf{E}$ - Mean values of the proliferating keratinocytes number in the basal layer epidermis after subcutaneous implantation of various hydrogels (Ag/PVA - 7p.i.d.:30p.i.d., $p=0.004 ;$ 7p.i.d.:60p.i.d., $p<0.001 ;$ 15p.i.d.:30p.i.d., $p=0.048$; 15p.i.d.:60p.i.d., $\mathrm{p}<0.001$; 30p.i.d.:60p.i.d., $\mathrm{p}=0.001$. Ag/PVA/Gr - 7p.i.d.:30p.i.d., $\mathrm{p}<0.001$; 7p.i.d.:60p.i.d., $\mathrm{p}<0.001$; 15p.i.d.:30p.i.d., $\mathrm{p}=0.003$; 15p.i.d.:60p.i.d., $\mathrm{p}<0.001$; 30p.i.d.:60p.i.d., $\mathrm{p}=0.049$. Suprasorb ${ }^{\circledR}$ - 7p.i.d.:15p.i.d., $\mathrm{p}<0.001$; 7p.i.d.:30p.i.d., $\mathrm{p}<0.001$; 7 p.i.d.:60p.i.d., $\mathrm{p}=0.039$; 15p.i.d.:60p.i.d., $\mathrm{p}<0.001$; 30p.i.d.:60p.i.d., $\mathrm{p}=0.002$. 


\section{DISCUSSION}

In this study, we analyzed the Ag/PVA and novel Ag/PVA/Gr hydrogels and the tissue response they evoke, by using IHC methods which enable visualization of the skin regenerative processes. Hydrogels can be applied to wounds, which can stimulate various processes important for skin regeneration [28]. In our study, for both tested hydrogels Ag/PVA and Ag/PVA/Gr, there was a solid vessel density in the wound bed, while in the case of the bioinert commercial Suprasorb ${ }^{\circledR}$ angiogenesis was not prominent, except on the $7^{\text {th }}$ p.i.d. The expression of $\alpha$-SMA in the tissue surrounding $\mathrm{Ag} / \mathrm{PVA}$ and Ag/PVA/Gr hydrogels shows that blood vessels occupy 30\% to 50\% of the capsule zone and $10 \%$ to $30 \%$ of the pericapsular connective tissue, in all observed time periods, which indicates active angiogenesis necessary for healing. Damaged tissue reparation, stimulated by biomaterials has to follow the natural tissue healing processes, so the wound dressing has to fulfill many requirements [34-37]. Growth factors and cytokines are secreted at the site of injury in the recovering tissue, new blood vessels and extracellular matrix (ECM) are initially formed at the site of reparation in the following order: (1) migration and proliferation of fibroblasts at the site of the defect followed by collagen production; (2) ECM deposition and finally, (3) tissue remodeling $[36,38,39]$.

Laminins and related ECM components, have essential roles in tissue homeostasis and during wound healing, they take part in the skin renewal process $[39,40]$ Our research noted that after implantation of $\mathrm{Ag} / \mathrm{PVA}$ and $\mathrm{Ag} / \mathrm{PVA} / \mathrm{Gr}$, the distribution of laminin in the tissue was high in various skin cells, including epithelial cells, muscle and endothelial cells, as well as in the ECM of the dermis, and connective tissue capsules. These findings are consistent with literature data [41-43], although the results obtained in the implant zone cannot be compared with data of other authors, since there have not been in vivo studies with newly synthesized Ag/PVA/Gr so far. The increased expression of laminin in the case of $\mathrm{Ag} / \mathrm{PVA} / \mathrm{Gr}$ in all observed time periods, in relation to the intact skin control, is a consequence of its involvement in cell migration, adhesion and differentiation during active tissue remodeling induced by implanted material itself.

The ECM acts not only as a mechanical scaffold for the cells, but also as a bioactive and dynamic environment that mediates cellular functions [44,45]. Fibrillar collagen forms a large part of the connective tissue at the site of reparation [46]. Collagen synthesis begins 3 to 5 days after injury and lasts for several weeks, depending on the size of the wound [1]. The net accumulation of collagen does not depend only on increased synthesis, but also on reduced degradation [43]. Collagen is the most abundant component of the ECM, and is directly linked to cell differentiation processes [46]. According to the obtained results, at the end of the monitoring period $\left(60^{\text {th }}\right.$ p.i.d.) a mild expression of type I and type III collagen, as well as a significant density of blood vessels were registered in the capsule following Ag/PVA and Ag/PVA/Gr implantation, indicating that the applied hydrogels led to a small degree of fibrosis and 
significant neovascularization of the periimplant zone. Similar values were obtained for both hydrogels Ag/PVA and Ag/PVA/Gr. This data supports their biocompatibility, since the degree of biocompatibility is inversely proportional to collagen density in the connective tissue capsule, and directly proportional to angiogenesis [27]. Comparing intact skin control and the skin after implantation of all three hydrogels (Ag/PVA and Ag/PVA/Gr, Suprasorb () , the type I and III collagen were expressed in the connective tissue of the dermis, hypodermis and cutaneous muscle, with the highest expression being in the dermis. The capsule, pericapsular zone and subcutaneous connective tissue around Ag/PVA and Ag/PVA/Gr hydrogels had mild to moderate expression of type I and III collagen on the $15^{\text {th }}, 30^{\text {th }}$ and $60^{\text {th }}$ p.i.d., while the collagen

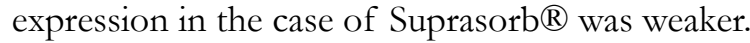

Remodeling is the last phase in the wound healing process [45]. It is tightly regulated by degradation and synthesis, leading to normal skin regeneration [44]. Tissue regeneration begins by restoring the tissue damage, firstly by removing dead cells, then by proliferation of progenitor cells and lastly, functional restoration of the tissue [42]. Apoptosis is involved in the processes of wound healing and tissue regeneration, with the basic role of removing inflammatory cells and granulation tissue $[47,48]$. Skin stem cells also play an important role in wound healing and tissue regeneration [49]. Keratinocyte proliferation is high on the $7^{\text {th }}$ p.i.d., although, highest keratinocytes proliferation values were observed in the case of the $\mathrm{Ag} / \mathrm{PVA}$ implant on the $15^{\text {th }}$ p.i.d. Both tested materials showed higher values in comparison with Suprasorb $®$. On the $30^{\text {th }}$ and $60^{\text {th }}$ day, these values gradually decreased, except for the significant leap in keratinocyte number in the case of Suprasorb ${ }^{\circledR}$ on the $60^{\text {th }}$ p.i.d. probably owing to the high degradability of this material, which indirectly promotes signaling molecules that stimulate migration and proliferation of stem cells in the skin.

Various hydrogels described in literature are widely accepted in clinical procedures for wound dressings, including hydrogels based on a PVA copolymer with silver nanoparticles (AgNPs/PVA) [49-51]. The presence of AgNPs in composite hydrogels with $\mathrm{Gr}$ accelerates the rate of the wound healing process in animal models [52]. Various experiments have demonstrated that Gr-based biomaterials have excellent cytocompatibility, which could lead to an increase in early adhesion, spreading, proliferation, and remodeling of cytoskeletons of fibroblast cells [53]. Based on a relatively long follow-up periods $(7,15,30,60$ days after implantation) of rats with subcutaneously implanted $\mathrm{Ag} / \mathrm{PVA}$ and $\mathrm{Ag} / \mathrm{PVA} / \mathrm{Gr}$, our results confirmed the biotolerance of the organism for these hydrogels [27]. The new Ag/PVA/Gr material synthesized by using nanotechnology techniques showed a wider connection area and a stronger implant-skin interface, potentiated by adhesive proteins that acted as a strong stimulus for signaling molecules and regenerative tissue response, thus speeding up repair processes and shortening the time necessary for tissue regeneration. Regarding the expertise of all in vivo biocompatibility assessments of new materials, it is crucial to choose the appropriate animal model. Another fact that must be taken into account, when interpreting results from these or similar studies, is the discrepancy in biological responses of organisms belonging to different species [54]. 


\section{CONCLUSION}

The evaluation of the tissue response and skin regeneration processes after Ag/PVA and $\mathrm{Ag} / \mathrm{PVA} / \mathrm{Gr}$ implantation indicates that these biotolerant and biocompatible hydrogels can absorb high volume of fluid and establish rapid solubility of nanomaterials in the tissue for a short period of time. Mild and weak reactions around the commercial Suprasorb ${ }^{\circledR}$ hydrogel were observed. We noted that both tested hydrogels contributed to the formation of a thin well-vascularized capsule with a moderate amount of collagen and the formation of pericapsular subcutaneous connective tissue. They consequently stimulated the invasion of immune and stem cells, which positively regulate regeneration processes in the skin. All these results demonstrate that $\mathrm{Ag} / \mathrm{PVA} / \mathrm{Gr}$ may be a prospective wound dressings for enhancing the wound healing process.

\section{Acknowledgments}

The study was supported by the Ministry of Education, Science and Technological Development of the Republic of Serbia (Contract number 451-03-9/2021-14/200143, 451-03-9/2021-14/200135 and 451-03-9/2021-14/200287).

The authors also wish to acknowledge the funding from European Commisson, project "Twinning to excel materials engineering for medical devices - ExcellMater" grant no. 952033, H2020-WIDESPREAD-2018-2020/H2020-WIDESPREAD-2020-5, 20202023.3

\section{Authors' contributions}

TLB, VT, VMS and DM participated in the study design, analyzed the data, and drafted the manuscript. TLB carried out the experimental part of the study and made a substantial contribution to conception, design and analysis, acquisition and interpretation of data. IM and VG were responsible for animal care and welfare. TLB, NI and VT performed immunohiostochemical analyses. VMS and KN carried out the novel hydrogels synthesis, as well as, supervised and facilitated the overall write-up. BBP performed the surgical procedures, including the implantation and removal of the hydrogels. TLB, IM and VG performed the statistical analysis. DM, VT, VMS and JSF were involved in the final drafting of the manuscript and revised it critically for important intellectual content. All authors discussed the results and contributed to the final manuscript.

\section{Declaration of conflicting interests}

The author(s) declared no potential conflicts of interest with respect to the research, authorship, and/or publication of this article. 


\section{REFERENCES}

1. Smrke DM, Semenič D: The Role of Acellular Flowable Matrix in Tissue Regeneration. In: Cells and Biomaterials in Regenerative Medicine. Rijeka, Croatia; 2014, 261-270.

2. Zavan B, Cortivo R, Abatangelo G. Hydrogels and Tissue Engineering: In: Hydrogels Biological Properties and Applications. Milano, Italia; 2009, 1-9.

3. Ratner BD, Atzet S: Hydrogels for healing. In: Hydrogels Biological Properties and Applications. Milano, Italia; 2009, 43-51.

4. Batista NA, Rodrigues AA, Bavaresco VP, Mariolani JRL, Belangero WD: Polyvinyl alcohol hydrogel irradiated and acetalized for osteochondral defect repair: mechanical, chemical, and histological evaluation after implantation in rat knees. Internat J Biomat 2012, 2012:582685.

5. Hayes JC, Kennedy JE: An evaluation of the biocompatibility properties of a salt-modified polyvinyl alcohol hydrogel for a knee meniscus application. Mater Sci Eng C Mater Biol Appl 2016, 59:894-900.

6. Wu JQ, Liu Y, Yang TF, Mu YH, Guo T, Li YB: Porous polyvinyl alcohol hydrogel composite prepared and studied initially for biocompatibility. Sichuan Da Xue Xue Bao.Yi Xue Ban 2007, 38:705-708.

7. Oliviera RN, Rouzé R, Quilty B, Alves GG, Soares GDA, Thiré RMSM, McGuinness GB: Mechanical properties and in vitro characterization of polyvinyl alcohol-nano-silver hydrogel wound dressings. Interface Focus 2014, 4:20130049.

8. Chen H, Cheng R, Zhao X, Zhang Y, Tam A, Yan Y, Shen H, Zhang YS, Qi J, Feng Y, Lei L, Pan G, Cui W, Deng L: An injectable self-healing coordinative hydrogel with antibacterial and angiogenic properties for diabetic skin wound repair. NPG Asia Materials 2019, 11(1):1-12.

9. Li J, Wang J, Wang Z, Xia Y, Zhou M, Zhong A, Sun J: Experimental models for cutaneous hypertrophic scar research. Wound Rep Reg 2020, 28:126-144.

10. Stojkovska J, Djurdjević Ž, Jančić I, Bufan B, Milenković M, Janković R, Misković-Stanković $\mathrm{V}$, Obradović B: Comparative in vivo evaluation of novel formulations based on alginate and silver nanoparticles for wound treatments. J Biomat Appl 2018, 32(9):1197-1211.

11. Wang F, Wang X, Ma K, Zhang C, Chang J, Fu X: Akermanite bioceramic enhances wound healing with accelerated reepithelialization by promoting proliferation, migration, and stemness of epidermal cells. Wound Rep Reg 2020, 28:16-25.

12. Nešović K, Janković A, Perić-Grujić A, Vukašinović-Sekulić M, Radetić T, Živković Lj, Park SJ, Rhee KY, Mišković-Stanković V: Kinetic models of swelling and thermal stability of silver/poly(vinyl alcohol)/chitosan/graphene hydrogels. J Ind Eng Chem 2019, 77:8396.

13. Surudžić R, Janković A, Mitrić M, Matić I, Juranić ZD, Živković L, Mišković-Stanković V, Rhee KY, Park SJ, Hui D: The effect of graphene loading on mechanical, thermal and biological properties of poly(vinyl alcohol)/graphene nanocomposites. J Ind Eng Chem 2016, 34:250-257.

14. Jose J, Al-Harthi MA, AlMa'adeed MAA, Dakua JB, De SK: Effect of graphene loading on thermomechanical properties of poly(vinyl alcohol)/starch blend. J Appl Polym Sci 2015, 132(16):41827.

15. Usman A, Hussain Z, Riaz A, Khan AN: Enhanced mechanical, thermal and antimicrobial properties of poly(vinyl alcohol)/graphene oxide/starch/silver nanocomposites films. Carbohydr Polym 2016, 153:592-599. 
16. Hegab HM, Elmekawy A, Zou L, Mulcahy D, Saint CP, Ginić-Marković M: The controversial antibacterial activity of graphene-based materials. Carbon 2016, 105:362-376.

17. Kurapati R, Martin C, Palermo V, Nishina Y and Bianco A: Biodegradation of graphene materials catalyzed by human eosinophil peroxidise. Faraday discussions 2020, 227:189-203

18. Bianchera A, Catanzano O, Boateng J, Elviri L: The Place of Biomaterials in Wound Healing. In: Therapeutic Dressings and Wound Healing Applications. New Jersey, USA; 2019, 337-336.

19. Chu J, Shi P, Yan W, Fu J, Yang Z, He C, Deng X, Liu H: Pegylated graphene oxide-mediated quercetin-modified collagen hybrid scaffold for enhancement of MSCs differentiation potential and diabetic wound healing. Nanoscale 2018, 10: 9547.

20. Rakhshaei R, Namazi H, Hamishehkar H, Rahimi M: Graphene quantum dot crosslinked carboxymethyl cellulose nanocomposite hydrogel for $\mathrm{pH}$-sensitive oral anticancer drug delivery with potential bioimaging properties. International Journal of Biological Macromolecules 2020, 1121-1129.

21. Nowroozi N, Faraji S, Nouralishahi A, Shahrousvand M: Biological and structural properties of graphene oxide/curcumin nanocomposite incorporated chitosan as a scaffold for wound healing application. Life Sciences 2021, 264:118640.

22. Nešović K, Janković A, Radetić T, Vukašinović-Sekulić M, Kojić V, Živković L, PerićGrujić A, Rhee KY, Mišković-Stanković V: Chitosan-based hydrogel wound dressings with electrochemically incorporated silver nanoparticles - In vitro study. Eur Polym J 2019, 121:109257.

23. Nešović K, Abudabbus MM, Rhee KY, Mišković-Stanković V: Graphene Based Composite Hydrogel for Biomedical Applications. Croat Chem Acta 2017, 90(2):207-213.

24. Pencheva D, Bryaskova R, Kantardjiev T: Polyvinyl alcohol/silver nanoparticles (\{PVA/ $\mathrm{AgNps}\}$ ) as a model for testing the biological activity of hybrid materials with included silver nanoparticles. Mater Sci Eng C 2012, 32:2048-2051.

25. Mišković-Stanković V, Jevremović I, Janković A: Patent application no. P-2015/0784, The Intellectual Property Office of the Republic of Serbia, dated 25.11.2015.

26. Abudabbus MM, Jevremović I, Janković A, Perić-Grujić A, Matić I, Vukašinović-Sekulić M, Hui D, Rhee KY, Mišković-Stanković V: Biological activity of electrochemically synthesized silver doped polyvinyl alcohol/graphene composite hydrogel discs for biomedical applications. Compo. Part B Eng 2016, 104:26-34.

27. Lužajić Božinovski T, Marković D, Todorović V, Prokić BB, Milošević I, Drndarević N, Nešović K, Rhee KY, Mišković-Stanković V: In Vivo Investigation of Soft Tissue Response of Novel Silver/Poly (Vinyl Alcohol)/Graphene and Silver/Poly (Vinyl Alcohol) /Chitosan/ Graphene Hydrogels Aimed for Medical Applications-The First Experience. Acta Vet 2018, 68:321-339.

28. Engel H, Kao SW, Larson J, Uriel S, Jiang B, Brey EM, Cheng MH: Investigation of dermis-derived hydrogels for wound healing applications. Biomed J 2015, 38:58-64.

29. Monteiro-Riviere NA, Bristol DG, Manning TO, Rogers RA, Riviere JE: Interspecies and interregional analysis of the comparative histologic thickness and laser Doppler blood flow measurements at five cutaneous sites in nine species. J Invest Dermatol 1990, 95:582-586.

30. Grada A, Mervis J, Falanga V: Research Techniques Made Simple: Animal Models of Wound Healing. J Invest Dermatol 2018, 138:2095-2105.

31. Dorsett-Martin WA and Wysocki AB: Rat Models of Skin Wound Healing. In: Sourcebook of models for biomedical research. New Jersey, USA; 2008, 631-639. 
32. Rand MS: Selection of Biomedical Animal Models. In: Sourcebook of models for biomedical research. New Jersey, USA; 2008, 9-15.

33. Pastar I, Wong LL, Egger AN, Tomic-Canic M: Descriptive vs mechanistic scientific approach to study wound healing and its inhibition: Is there a value of translational research involving human subjects? Exp Dermatol 2018, 27(5):551-562.

34. Mir M, Ali MN, Barakullah A, 'Gulzar A, Arshad M, Fatima S, Asad M: Synthetic polymeric biomaterials for wound healing: a review. Progress in Biomat 2018, 7:1-21.

35. Kumar S, Wong PF, Leaper DJL: What is new in wound healing? Turk J Med Sci 2004, 34:147-160.

36. Todorović V, Peško P, Micev M, Bjelović M, Budeč M, Mićić M, Brašanac D, Ilić-Stojanović O: Insulin-like growth factor-I in wound healing of rat skin. Reg Pept 2008, 150:7-13.

37. Cornwell KG, Landsman A, James KS: Extracellular matrix biomaterials for soft tissue repair. Clin Podiatr Med Surg 2009, 26:507-523.

38. Daley WP, Peters SB, Larsen M: Extracellular matrix dynamics in development and regenerative medicine. J Cell Sci 2008, 121:255-264.

39. Iorio V, Troughton LD, Hamill KJ. Laminins: Roles and Utility in Wound Repair. Adv Wound Care 2015, 4(4):250-263.

40. Yousif LF, Russo JD, Sorokin L: Laminin isoforms in endothelial and perivascular basement membranes. Cell Adhes Migr 2013, 7:101-110.

41. Geckil H, Xu F, Zhang X, Moon SJ, Demirci U: Engineering hydrogels as extracellular matrix mimics. Nanomedicine (Lond) 2010, 5(3):469-484.

42. Santos ARJR, Nascimento CVA, Genari SC, Lombelloc CB: Mechanisms of Cell Regeneration - From Differentiation to Maintenance of Cell Phenotype. In: Cells and Biomaterials in Regenerative Medicine. Rijeka, Croatia; 2014, 37-69.

43. Han G, Ceilley R: Chronic wound healing: A review of current management and treatments. Adv Ther 2017, 34(3):599-610.

44. Baum CL, Arpey CJ. Normal cutaneous wound healing: clinical correlation with cellular and molecular events. Dermatol Surg 2005, 31(6):674-686.

45. Reinke JM, Song H. Wound repair and regeneration. Eur Surg Res 2012, 49:35-43.

46. Yates CC, Hebda P, Wells A. Skin wound healing and scarring: fetal wounds and regenerative restitution. Birth Defects Res C Embryo Today 2012, 96:325-333.

47. Costanzo A, Fausti F, Spallone G, Moretti F, Narcisi A, Botti E: Programmed cell death in the skin. Int J Dev Biol 2015, 59(1-3):73-78.

48. Ojeh N, Pastar I, Tomic-Canic M, Stojadinovic O: Stem Cells in Skin Regeneration, Wound Healing and Their Clinical Applications. Int J Mol Sci 2015, 16(10):25476-25501.

49. Li C, Fu R, Yu C, Li Z, Guan H, Hu D, Zhao D, Lu L: Silver nanoparticle/chitosan oligosaccharide/poly(vinyl alcohol) nanofibers as wound dressings: a preclinical study. Int J Nanomedicine 2013, 8:4131-4145.

50. Abdelgawad AM, Hudson SM, Rojas OJ: Antimicrobial wound dressing nanofiber mats from multicomponent (chitosan/silver-NPs/polyvinyl alcohol) systems. Carbohydr Polym 2014, 100:166-178.

51. Gonzalez JS, Ludueña LN, Ponce A, Alvarez VA. Poly (vinyl alcohol)/ cellulose nanowhiskers nanocomposite hydrogels for potential wound dressings. Mater Sci Eng C Mater Biol Appl 2014, 34:54-61. 
52. Fan Z, Liu B, Wang J, Zhang S, Lin Q, Gong P, Ma L, Yang S: A novel wound dressing based on Ag/graphene polymer hydrogel: effectively kill bacteria and accelerate wound healing. Adv Funct Mater 2014, 24:3933-3943.

53. Han S, Sun J, He S, Tang M, Chai R: The application of graphene-based biomaterials in biomedicine. Am J Transl Res 2019, 11(6):3246.

54. Prokić BB, Lužajić Božinovski T, Gajdov V, Milošević I, Todorović V, Đošić M, MiškovićStanković V, Marković D: Animal models in bicompatibility assessments of implants in soft and hard tissues. Veterinarski Glasnik, 2021, 00: 1-16. https://doi.org/10.2298/ VETGL210322005P

\title{
PROCENA REGENERATIVNIH PROCESA MEKIH TKIVA NAKON SUPKUTANE IMPLANTACIJE SREBRO / POLI (VINIL ALKOHOL) I NOVOG SREBRO / POLI (VINIL ALKOHOL) / GRAFENSKOG HIDROGELA NA ANIMALNOM MODELU
}

\author{
Tijana LUŽAJIĆ BOŽINOVSKI, Vera TODOROVIĆ, Ivan MILOŠEVIĆ, \\ Vladimir GAJDOV, Bogomir Bolka PROKIĆ, Katarina NEŠOVIĆ, \\ Vesna MIŠKOVIĆ-STANKOVIĆ, Danica MARKOVIĆ
}

Bilo koji novoproizvedeni biomaterijal nužno podleže standardima, po čijim se protokolima sprovode in vivo istraživanja na životinjskim modelima. Za procenu mogućnosti regeneracije mekog tkiva nakon potkožne implantacije biomaterijala - srebra/poli(vinil alkohola) (Ag/PVA) i novog materijala srebra/poli(vinil alkohola)/grafena (Ag/PVA/ Gr) predviđenog za kliničku upotrebu, šesnaest pacova je korišćeno, po uputstvima međunarodnog standarda, ISO 10993-6 2007. Histološki uzorci su sakupljeni 7, 15, 30 i 60 dana nakon implantacije. Ovi hidrogelovi su proizvedeni in situ elektrohemijskom sintezom nanočestica srebra u polimernim matricama, što je omogućilo dobijanje potpuno sigurnih i biokompatibilnih materijala, bez ikakvih dodatnih toksičnih hemijskih sredstava za redukciju. Hirurška implantacija hidrogela urađena je prema dozvoli Etičkog komiteta Fakulteta veterinarske medicine Univerziteta u Beogradu. Imunohistohemijske (IHC) studije uključivale su procenu ekspresije aktina glatkih mišića u krvnim sudovima ( $\alpha$-SMA), ekspresiju laminina i kolagena tipa I i III u strukturama kože i određivanje ekspresije markera proliferacije (Ki-67) keratinocita. Rezultati su procenjeni semikvantitativnom analizom. Podaci su analizirani u statističkom softverskom paketu IBM SPSS 20. Zaključci su ukazali da se Ag/PVA/Gr može koristiti kao obloga za rane kako bi se povećao potencijal zarastanja tkiva i uspostavila brža integracija i kraće zadržavanje u tkivu. 